\title{
KERJASAMA LUAR NEGERI DI ERA OTONOMI DAERAH (PERAN PEMDA DAN MEKANISME MEMULAI KERJASAMA)
}

\author{
Luerdi \\ Mahasiswa Pascasarjana Ilmu Politik Universitas Riau
}

\section{Citation as}

Luerdi, L. (2014). Kerjasama Luar Negeri di Era Otonomi Daerah (Peran Pemda dan Mekanisme Memulai Kerjasama). https://doi.org/10.31219/osf.io/dbpem 


\title{
Kerjasama Luar Negeri di Era Otonomi Daerah \\ (Peran Pemda dan Mekanisme Memulai Kerjasama)'
}

\author{
Luerdi \\ Mahasiswa Pascasarjana Ilmu Politik Universitas Riau
}

\section{Peran Pemda dalam Kerjasama Luar Negeri}

Sejak dibukanya kran otonomi daerah di Indonesia, setiap pemerintah daerah (pemda) mulai mendapatkan kewenangan yang besar dalam mengelola potensi daerahnya sendiri. Perjalanan otonomi daerah telah menunjukkan berbagai perubahan tentang hubungan pusat dengan daerah termasuk dalam hal kerjasama luar negeri. Pemerintah pusat tidak lagi menjadi aktor satu-satunya dalam menjalin hubungan luar negeri dengan pihak asing. Kini pemda diberikan ruang untuk mengadakan kerjasama luar negeri dengan pihak asing baik itu dengan pemda asing dalam bentuk sister province (setingkat propinsi/negara bagian/perfektur) dan sister city (setingkat kabupaten/kota/county), maupun dengan pihak swasta asing, organisasi internasional di bawah PBB, dan lembaga swadaya masyarakat asing.

Undang-undang (UU) No.32 Tahun 2004 tentang Pemerintahan Daerah dan berbagai peraturan lainnya telah mengizinkan pemda memprakarsai dan melaksanakan kerjasama luar negeri namun tetap berada dalam kerangka kedaulatan NKRI. Artinya pemda harus berkoordinasi dengan dan mendapatkan persetujuan dari pemerintah pusat sesuai dengan prosedur yang telah ditetapkan. Pemda dapat melakukan kerjasama dengan pihak asing dalam berbagai bidang kecuali bidang-bidang yang menjadi wewenang

\footnotetext{
${ }^{1}$ Bahan diskusi perkuliahan pada Program Studi Ilmu Politik Pascasarjana Universitas Riau (2013-2014).
} 
pemerintah pusat seperti politik luar negeri, pertahanan, kemananan, yustisi, moneter dan fiskal nasional, dan agama. ${ }^{2}$

Dengan adanya distribusi kewenangan yang diberikan kepada pemda, setiap pemda di Indonesia seharusnya menangkap peluang melakukan kerjasama luar negeri untuk memberdayakan seluruh potensi yang ada di daerahnya baik itu sumber daya alam maupun sumber daya manusia. Dalam beberapa kasus kerjasama luar negeri yang dilakukan oleh pemda-pemda di Indonesia, program kerjasama yang dikelola dengan baik dan terencana memberikan berbagai manfaat kepada daerah-daerah yang bersangkutan seperti terjadinya alih teknologi, peningkatan kualitas sumber daya manusia, pendidikan dan perekonomian masyarakat setempat, percepatan pembangunan dan manfaat-manfaat lainnya.

Praktik kerjasama pemda di Indonesia dengan luar negeri yang sering dijadikan inspirasi adalah kerjasama antara propinsi DI.Yogyakarta dengan perfektur Kyoto (Jepang) dengan model sister province yang mulai dirintis sejak tahun 1985. ${ }^{3}$ Kini hubungan kerjasama antar kedua pemda tersebut masih berlanjut dan telah mengalami perkembangan dan perluasan dalam berbagai bidang. Dibandingkan dengan propinsi-propinsi lain di Indonesia, propinsi-propinsi di daerah Jawa dan Bali nampaknya lebih berpengalaman dan tercatat paling banyak melakukan kerjasama luar negeri. ${ }^{4}$

Dalam praktik kerjasama luar negeri dengan pihak asing, tingkat efektifitas kerjasama dilakukan oleh pemda sangat beragam. Beberapa kasus menunjukkan pemda-pemda relatif berhasil dalam mendapatkan tujuan-tujuan yang telah direncanakan dari adanya kerjasama luar negeri tersebut. Namun, banyak pula pemda yang tidak dapat mengimplementasikan berbagai

\footnotetext{
${ }^{2}$ Kementerian Luar Negeri Republik Indonesia., Panduan Umum; Tata Cara Hubungan dan Kerjasama Luar Negeri oleh Pemerintah Daerah, Revisi Tahun 2006, Jakarta, 2012, hal. 12.

${ }_{3}^{3}$ Antara Kyoto, Yogyakarta, dan Pendidikan., 01 Agustus 2011 , <http://www.pendidikandiy.go.id/dinas_v4/?view=v_berita\&id_sub=2520\#sthash.s9w5SgkK.dpuf>, [diakses 05 Desember 2014].

${ }^{4}$ Hubungan Kerjasama Luar Negeri oleh Pemerintah Daerah., <http://otdaksm.jabarprov.go.id/ upload/Kerjasama\%20Luar\%20Negeri\%20oleh\%20Pemda.pdf>, [diakses 06 Desember 2014].
} 
kesepakatan atau memorandum of understanding (MoU) yang telah ditandatangani. Bahkan ada juga pemda hanya sekedar melakukan penjajakan ke daerah negara lain atau menerima kunjungan dari pemda propinsi negara lain, tapi tidak ada tindak-lanjut dari kegiatan tersebut.

Efektifitas pelaksanaan kerjasama luar negeri yang dilakukan oleh pemda secara umum tergantung pada pemda itu sendiri. Pemda-pemda yang umumnya berhasil melaksanakan kerjasama luar negeri memahami potensi daerahnya dan potensi tersebut akan dapat diberdayakan dengan adanya kerjasama dengan pihak asing bila tidak dapat dikelola sendiri secara optimal. Ini tidak terlepas dari visi kepemimpinan pemda untuk meningkatkan kualitas kehidupan masyarakat di daerahnya. Kendala teknis, sumber daya manusia, dan alasan finansial tidak dinafikan menjadi kendala pelaksanaan kerjasama luar negeri oleh pemda. Namun pemahaman pemda dalam memposisikan daerahnya dengan realitas globalisasi akan mendorong pemda tersebut memanfaatkan peluang-peluang yang ada demi kemajuan daerahnya.

Otonomi daerah telah membagi peran-peran yang dapat dijalankan oleh pemerintah pusat dan pemerintah daerah. Dalam kerjasama luar negeri, pemerintah pusat lebih fokus pada pembuatan regulasi dan pemberi fasilitas dalam menjalankan hubungan kerjasama, termasuk menyusun peraturan dan prosedur yang mudah untuk diaplikasikan dalam hubungan kerjasama tersebut. 5 Sedangkan pemda diamanahkan untuk memanfaatkan segala potensi yang dimiliki daerahnya dengan berbagai kebijakan termasuk kebijakan melakukan kerjasama luar negeri dengan pihak asing selagi bermanfat bagi kepentingan daerahnya dan tidak merugikan kepentingan nasional. Dengan kondisi seperti ini, pemda seharusnya dapat berperan aktif dalam menangkap peluang-peluang yang ada.

\footnotetext{
${ }^{5}$ M. Saeri., Peran Pemerintah Daerah dalam Kerjasama Internasional., hal. 8-9, <repository.unri.ac.id/xmlui/bitstream/>, [diakses 14 Desember 2014].
} 


\section{Beberapa Contoh Kerjasama Luar Negeri oleh Pemda}

Berbagai bentuk kerjasama telah dilakukan oleh beberapa pemda dengan pihak-pihak asing di luar negeri baik dengan pemda asing dalam bentuk sister province dan sister city, maupun dengan pihak swasta asing, organisasi internasional, dan LSM asing. Berikut ini adalah beberapa contoh kerjasama luar negeri yang dilakukan oleh pemda:

1. Kerjasama pemda Jawa Barat (Jabar) dengan pemda Cholanamdo (Republik Korea). ${ }^{6}$

Kerjasama yang dilakukan oleh pemda Jabar dan pemda Cholanamdo tersebut merupakan kerjasama dalam bidang perikanan. Pemda Cholanamdo bersedia memberikan program bantuan pengadaan armada penangkapan ikan sebesar 15 milyar kepada para nelayan di Jabar. Penegasan MoU kerjasama tersebut ditopang persetujuan DPRD Jabar melalui Keputusan DPRD Propinsi Jabar No.193/Kep-DPRD 44/2000. Kemudian secara teknis MoU tersebut diikuti dengan penerbitan full powers (surat kuasa menteri luar negeri) pada tanggal 15 Januari 2001. Secara teknis, kerjasama ini diserahkan pada biro sarana dan ekonomi (sarek) sekda pemda Jabar.

2. Pemda Jabar dengan BnV LLC (Perusahaan Swasta Asing Amerika Serikat). ${ }^{7}$

Kerjasama Pemda Jawa Barat dengan swasta asing tersebut dimaksudkan untuk meningkatkan promosi bidang perdagangan terutama sektor usaha kecil dan menengah, investasi, kepariwisataan dan budaya Jabar di New York, Amerika Serikat. Instansi pelaksana yang ditunjuk oleh pemda Jabar untuk pelaksanaan kerjasama tersebut adalah dinas perindustrian dan perdagangan (disperindag) melalui

\footnotetext{
${ }^{6}$ Jawahir Thontowi., 'Kewenangan Daerah Dalam Melaksanakan Hubungan Luar Negeri (Studi Kasus di Propinsi Jawa Barat dan DIY)', dalam Jurnal Hukum No. 2 Vol. 16 April 2009, hal. 154. 7 ibid., hal. 155.
} 
Keputusan Gubernur Jabar No.501.1/Kep.387.Sarek/2003. Adapun jangka waktu pelaksanaan kerjasama tersebut adalah selama 5 Tahun.

3. Kerjasama pemda Jabar dengan Research Triangle Institute (RTI) Internasional Educational Development Center (EDC) (LSM Asing). ${ }^{8}$

Secara teknis kerjasama tersebut dilakukan dengan pemerintah kabupaten Indramayu dan Sukabumi. Adapun objek dari kerjasama tersebut adalah penyelenggaraan bantuan teknis USAID untuk peningkatan manajemen pendidikan dan tata pemerintahan. Selain itu, ruang lingkup kerjasama juga mengenai peningkatan mutu pembelajaran dan peningkatan keterampilan hidup masyarakat Jabar, khususnya di lokasi pelaksanaan kegiatan melalui program USAID tentang desentralisasi atau otonomi daerah.

4. Kerjasama pemda Jawa Tengah (Jateng) dengan pemda Queensland (Australia). ${ }^{9}$

Kerjasama luar negeri pemda Jateng ini pertama kali dimulai pada September 1991 sebagai respon dari kebijakan Australia pada negara bagian Queensland untuk melakukan kerjasama dengan dunia ke-tiga. Kerjasama tersebut pertama dimulai di bidang kesehatan kemudian berlanjut di bidang pendidikan, pertanian, pembangunan kota dan desa, industri, investasi dan bidang-bidang lainnya. MoU kerjasama tersebut ditandatangani oleh H.M. Ismail selaku Gubernur Jateng dan Wayne Goss selaku Premier Queensland kala itu. Masa berlaku kerjasama tersebut adalah lima tahun dan dapat diperpanjang kembali sesuai dengan kebutuhan. Untuk mempermudah jalannya kerjasama, pada tahun 1992 dibuka Queenslad Information Centre di Badan

\footnotetext{
8 ibid., hal. 156.

${ }^{9}$ Reni Windiani., Hubungan Luar Negeri Indonesia Era Otonomi Daerah; Studi Evaluasi Hubungan Sister Province (Provinsi Kembar) Jawa Tengah dengan Negara Bagian Queensland Australia Periode Tahun 2000-2007, hal. 2-7, <ejournal.undip.ac.id/download>, [diakses 04 Desember 2014].
} 
Penanaman Modal (BPM), dan pada tahun 1993 dibuka Cetral Java Information Centre di Milton Street, Brisbane.

5. Kerjasama pemda Gorontalo dengan pemda Selatan (Sri Lanka). ${ }^{10}$

Kerjasama antara pemda Gorontalo dan pemda propinsi Selatan merupakan salah satu contoh implementasi kerjasama luar negeri yang baik di era otonomi daerah. Kerjasama tersebut tidak didasarkan oleh persamaan keunggulan daerah tapi perbedaan yang dapat saling melengkapi. Gorontalo unggul dalam pertanian sedangkan propinsi Selatan unggul dalam bidang pendidikan. Pemda Gorontalo tertarik untuk mempelajari sistem pendidikan gratis yang diterapkan oleh propinsi Selatan, sedangkan pemda Selatan tertarik untuk mempelajari produksi dan pengelolaan jagung yang diterapkan oleh propinsi Gorontalo. Kerjasama ini dimediasi oleh ART-Gold UNDP. Selain itu UNDP juga memberikan bantuan teknis dan finansial sebagai bagian dari program kerjasama Selatan-Selatan.

6. Kerjasama pemda DI.Yogyakarta dengan pemda Kyoto (Jepang). ${ }^{11}$

Kerjasama sister province antara pemda Yogyakarta dan pemda Kyoto merupakan contoh kerjasama yang sering menjadi inspirasi bagi pemda-pemda di Indonesia untuk melakukan kerjasama dengan pihak asing. Kerjasama tersebut telah dimulai sejak tahun 1985, jauh sebelum adanya undang-undang ataupun berbagai peraturan berkaitan dengan otonomi daerah di Indonesia. Kerjasama tersebut lebih didasarkan pada berbagai persamaan yang miliki dalam hal sejarah dan budaya karena kedua daerah tersebut memiliki latar belakang sejarah yang mirip dan sama-sama kental akan nilai-nilai budaya. Kini kerjasama

\footnotetext{
${ }^{10}$ Slamet Rosyadi., Konsep Kerjasama Daerah Antar Negara dalam Kerangka Otonomi Daerah: Peluang dan Tantangan., makalah seminar Seminar Nasional Bappenas-AGI UNDP, Jakarta, tgl 24 Juni 2010, hal. 1-6, <http://asian.or.id/wp-content/uploads/2011/07/kerjasama-provinsislamet.pdf>, [diakses 14 Desember 2014].

${ }^{11}$ Kyoto Book Corner Jogja Library Center., 2011, <http://www.bpadjogja.info/post/berita/537 /kyoto-book-corner-jogja-library-center-html>, [diakses 15 Desember 2014].
} 
kedua daerah tersebut telah meliputi berbagai bidang seperti budaya, pendidikan, pariwisata, investasi, pertanian, dan bidang-bidang lainnya. Setiap tahun masyarakat Yogyakarta memperingari hari lahirnya kerjasama antara propinsi Yogyakarta dan perfektur Kyoto tersebut.

\section{Mekanisme Memulai Kerjasama}

Prakarsa kerjasama luar negeri dapat berasal dari pemda yang bersangkutan atau dari pemerintah pusat. Prakarsa dapat pula berasal dari pihak asing dengan menyampaikan maksud kerjasama melalui KBRI di negara tersebut kemudian KBRI meneruskan ke pemerintah pusat melalui Mementerian Luar Negeri. Gambaran tatacara memulai kerjasama luar negeri oleh pemda dapat dilihat dari Peraturan Menteri Dalam Negeri No.3 Tahun 2008 tentang Pedoman Pelaksanaan Kerjasama Pemda dengan Pihak Luar Negeri.

Berikut ini adalah contoh atau gambaran abstrak kerjasama luar negeri setingkat kabupaten yang dilakukan oleh pemda Rokan Hulu. Katakanlah pemda Rokan Hulu bermaksud untuk meningkatkan kualitas pendidikan dan sumber daya manusia di daerahnya dengan melakukan kerjasama sister city dengan salah satu daerah di negara bagian Malaka (Malaysia). Menurut pemda Rohul, Malaka merupakan negara bagian yang memiliki kualias pendidikan yang baik yang dapat dijadikan partner dalam memajukan pendidikan tingkat menengah dan tingkat atas di Rokan Hulu. Kerjasama tersebut direncanakan berlaku selama tiga tahun dan dapat dilanjutkan bila dianggap perlu.

Pemda Rokan Hulu bermaksud melakukan kerjasama sister school meliputi saling tukar delegasi beberapa kepala sekolah, guru, dan pelajar, pelatihan bersama penanggung jawab pendidikan seperti kepala dinas pendidikan dan kepala sekolah-kepala sekolah, dan berbagai kegiatan bersama lainnya. Pemda Rokan Hulu menargetkan terwujudnya beberapa 
sekolah percontohan dengan kualitas pendidikan internasional dan sumber daya manusia yang berwawasan global dan melek teknologi. Untuk menjamin implementasi kerjasama tersebut, pemda Rokan Hulu membentuk tim adhoc yang berada di bawah dinas pendidikan yang bertanggungjawab dalam mengumpulkan seluruh informasi yang penting terkait dengan peluang, tantangan, dan kendala kerjasama, pemecahan masalah, serta melakukan evaluasi berkala terhadap pencapaian tujuan yang telah ditetapkan pemda Rokan Hulu dari kerjasama tersebut.

Adapun alokasi sumber dana untuk mendukung kerjasama sama tersebut berasal dari APBD Rokan Hulu, APBD Riau, bantuan dana dari pemerintah pusat, dan sumber dana lain yang disepakati oleh kedua belah pihak yang melakukan kerjasama. Bila memungkinkan pemda Rokan Hulu meminta pemerintah pusat melalui Kementerian Luar Negeri untuk mengandeng UNESCO atau UNDP dalam pelaksanaan kerjasama tersebut baik untuk kebutuhan teknis maupun finansial.

Untuk memulai kerjasama tersebut, pemda Rohan Hulu harus melewati bebarapa tahap yang diatur dalam Permendagri No.3 Tahun 2008. Adapun tahap-tahap (mekanisme) yang harus dilalui oleh pemda Rokan Hulu adalah sebagai berikut: ${ }^{12}$

Pertama, pemda Rokan Hulu dapat melakukan penjajakan ke daerah luar negeri yang dijadikan target kerjasama (katakanlah salah satu daerah di negara bagian Malaka). Pemda Rohul dapat bertukar informasi atau melakukan diskusi tentang peluang kerjasama di bidang pendidikan antara kedua pihak. Pemda Rokan Hulu dapat menawarkan model atau konsep kerjasama yang saling menguntungkan kedua belah pihak. Selain itu kedua belah pihak dapat menyepakati apakah kerjasama tersebut dapat melibatkan

\footnotetext{
${ }^{12}$ Peraturan Menteri Dalam Negeri No.3 Tahun 2008 tentang pedoman pelaksanaan kerjasama pemda dengan pihak luar negeri., <http://www.gitews.org/peraturan_menteri/Permendagri\%20032008Kerjasama\%20daerah\%20dengan\%2oLuar\%20Negeri.pdf>, [diakses 15 Desember 2014].
} 
pihak ke-tiga. Tahap penjajakan tersebut difasilitasi oleh KBRI yang ada di Malaysia. Penjajakan dapat dilakukan kembali bila dianggap perlu, misal penjajagan selanjutnya dapat dilakukan oleh pihak pemda di Malaka ke daerah Rokan Hulu.

Ke-dua, bila kedua belah pihak berpeluang untuk melakukan kerjasama, maka Bupati Rokan Hulu melalui Gubernur Riau melaporkan dan mengkonsultasikan prakarsa kerjasama tersebut kepada Menteri Dalam Negeri (Mendagri) untuk mendapatkan pertimbangan. Pertimbangan tersebut akan menjadi dasar dalam menyusun rencana kerjasama (Pasal 9).

Ke-tiga, setelah mendapat pertimbangan dari Mendagri, pemda Rokan Hulu dapat menyusun rencana kerjasama yang memuat beberapa hal seperti subyek kerjasama, latar belakang, maksud, tujuan, dan sasaran, obyek/ruang lingkup kerjasama, hasil kerjasama, sumber pembiayaan, dan jangka waktu pelaksanaan (pasal 11).

Ke-empat, rencana kerjasama yang telah dirancang disampaikan oleh Bupati Rokan Hulu kepada DPRD Rokan Hulu untuk mendapat persetujuan melalui keputusan DPRD. Bila DPRD Rokan Hulu menyetujui rencana kerjasama tersebut, pemda Rokan Hulu dapat menyusun rancangan momorandum of understanding (MoU) paling lambat 30 hari setelah rencana kerjasama mendapat persetujuan DPRD (pasal 12).

Ke-lima, Bupati Rokan Hulu melalui Gubernur Riau menyampaikan rencana kerjasama yang telah disetujui, persetujuan DPRD Rokan Hulu, dan rancangan MoU kepada Mendagri (pasal 13). Kemudian Mendagri membahas rencana kerjasama dan rancangan MoU tersebut dengan melibatkan departemen/lembaga pemerintah non-departemen terkait untuk memperoleh pertimbangan (pasal 14).

Ke-enam, rencana kerjasama dan rancangan MoU hasil pembahasan disampaikan oleh Mendagri kepada Menteri Sekretaris Negara (Mensesneg) untuk mendapat persetujuan pemerintah (pasal 14). 
Ke-tujuh, setelah mendapatkan pertujuan pemerintah, Mendagri melakukan koordinasi dengan Menteri Luar Negeri (Menlu) untuk menerbitkan full powers atau surat kuasa penuh. Full powers dapat diterbitkan setelah mendapat tanda persetujuan dari pihak luar negeri yang akan terlibat kerjasama. Full powers menjadi dasar untuk menandatangani Mou oleh pemda dan pihak luar negeri (pasal 14).

Ke-delapan, pemda Rokan Hulu dan pemda daerah negara bagian Malaka dapat bertemu dan menandatangani MoU tersebut. Penandatanganan MoU tersebut manjadi tanda bahwa kerjasama pendidikan yang telah direncanakan oleh kedua belah pihak dapat memasuki tahap implementasi.

\section{Kesimpulan}

Otonomi daerah telah memberikan peluang yang luas kepada setiap pemda untuk mengoptimalkan pemberdayaan potensi daerahnya termasuk dengan melakukan kerjasama dengan pihak luar negeri. Beberapa daerah (propinsi dan kabupaten/kota) telah merasakan berbagai manfaat kerjasama dengan pihak luar negeri. Walau tidak semua kerjasama luar negeri yang dilakukan oleh pemda-pemda berjalan dengan efektif dan banyak pula yang berhenti di jalan, kerjasama sama luar negeri tetap perlu dilakukan oleh pemda untuk meningkatkan kualitas perekonomian dan sumber daya manusia setempat. Dalam kasus kerjasama luar negeri yang diprakarsai oleh pemda setingkat kabupaten/kota, bupati/walikota harus berkoordinasi dengan Gubernur karena Gubernurlah yang berwenang menyampaikan rencana kerjasama dan melakukan berbagai bentuk koordinasi lainnya dengan pemerintah pusat. 


\section{Rererensi:}

Kementerian Luar Negeri Republik Indonesia., Panduan Umum; Tata Cara Hubungan dan Kerjasama Luar Negeri oleh Pemerintah Daerah, Revisi Tahun 2006, Jakarta, 2012.

Antara Kyoto, Yogyakarta, dan Pendidikan., 01 Agustus 2011, <http://www. pendidikandiy.go.id/dinas_v4/?view=v_berita\&id_sub=2520\#sthash.s9w 5S9kK.dpuf>, [diakses 05 Desember 2014].

Hubungan Kerjasama Luar Negeri oleh Pemerintah Daerah., <http://otdaksm. jabarprov.go.id/upload/Kerjasama\%20Luar\%20Negeri\%20oleh\%20Pemda. pdf>, [diakses 06 Desember 2014].

M. Saeri., Peran Pemerintah Daerah dalam Kerjasama Internasional., <repository.unri.ac.id/xmlui/bitstream/>, [diakses 14 Desember 2014].

Jawahir Thontowi., 'Kewenangan Daerah Dalam Melaksanakan Hubungan Luar Negeri (Studi Kasus di Propinsi Jawa Barat dan DIY)', dalam Jurnal Hukum No. 2 Vol. 16, April 2009.

Reni Windiani., Hubungan Luar Negeri Indonesia Era Otonomi Daerah; Studi Evaluasi Hubungan Sister Province (Provinsi Kembar) Jawa Tengah dengan Negara Bagian Queensland Australia Periode Tahun 2000-2007, <ejournal.undip.ac.id/download>, [diakses 04 Desember 2014].

Slamet Rosyadi., Konsep Kerjasama Daerah Antar Negara dalam Kerangka Otonomi Daerah: Peluang dan Tantangan., makalah seminar Seminar Nasional Bappenas-AGI UNDP, Jakarta, tgl 24 Juni 2010, $<$ http://asian.or.id/wp-content/uploads/2011/07/kerjasama-provinsislamet.pdf>, [diakses 14 Desember 2014].

Kyoto Book Corner Jogja Library Center., 2011, <http://www.bpadjogja.info/ post/berita/537/kyoto-book-corner-jogja-library-center-html>, [diakses 15 Desember 2014].

Peraturan Menteri Dalam Negeri No.3 Tahun 2008 tentang pedoman pelaksanaan kerjasama pemda dengan pihak luar negeri., <http://www. gitews.org/ peraturan_menteri/Permendagri\%20032008Kerjasama\%20 daerah\% 2odengan\%20Luar\%20Negeri.pdf>, [diakses 15 Desember 2014]. 